DOI: https://doi.org/10.32839/2304-5809/2020-12-88-11

удК 591.513 .3

Степко Л.О.

Одеський національний університет імені I.I. Мечникова

\title{
ПИТАННЯ ІМПРИНТИНГУ В СУЧАСНІЙ ЗООПСИХОЛОГІЇ
}

\begin{abstract}
Анотація. 3 моменту досліджень імпринтингу та його особливостей Конрадом Захаріасом Лоренцом, видатним австрійським зоологом, зоопсихологом, який став одним з засновників етологї, науки що вивчає генетично обумовлену поведінку (інстинкти) тварин, а так само складові частини інстинктивної поведінки, пройшло майже 100 років. За цей час, результати його досліджень і спостережень, стали фундаментом для багатьох фрахівців робота яких пов'язана з реабілітацією та розведенням птахів. Однак деякі проблеми що виникають в процесі роботи практиків 3 птахами, звертають на себе увагу. На даний момент стало зрозумілим, що окремі аспекти питання імпринтингу 30-х років ХХ ст. не були висвітленні повною мірою та потребують додаткової уваги та вивчення. Саме виділенню цих питань, неузгодженості результатів досліджень К. Лоренца зі спостереженнями сучасних орнітологів-практиків присвячена дана стаття.
\end{abstract}

Ключові слова: імпринтинг, зоопсихологія, орнітологія, відкарбовування, поведінка.

Stepko Lavrentiy

Odessa I.I. Mechnikov National University

\section{ISSUES OF IMPRINTING IN MODERN ZOOPSYCHOLOGY}

Summary. Almost 100 years have passed since the study of imprinting and its features by Konrad Zacharias Lorenz, a prominent Austrian zoologist, zoopsychologist, who became one of the founders of ethology, a science that studies genetically determined behavior (instincts) of animals, as well as components of instinctive behavior. During this time, the results of his research and observations have become the foundation for many professionals whose work is associated with rehabilitation centers. However, some problems that arise in the process of working with birds on the basis of such centers, attract attention. At the moment it has become obvious that some aspects of the issue of imprinting in the 30s of the twentieth century have not been fully covered and require additional attention and study. This article is devoted to the selection of these issues, the inconsistency of the results of K. Lorentz's research with the observations of modern ornithologists-practitioners. We are talking about the statement of Konrad Lorenz, which has become stereotypical among rehabilitologists, that imprinted birds are not able to mate, in other words, they leave reproduction, since the object of the first visual impression in their life was a person, and not a biological parent of a chick This leads to the fact that many rehabilitation therapists advocate the need to leave imprinted birds in captivity, which creates unfavorable conditions for both the rehabilitation centers themselves, which become overcrowded over time, needing funding, losing the opportunity to receive individuals who objectively need help and for the population birds left to keep in captivity. However, not everyone takes into account the fact that K. Lorenz conducted experiments mainly on ducks and geese, in whose broods the chicks appear fully formed. The issues of imprinting in birds, whose chicks are born not independent, needing parental care, have not yet been properly considered. In addition, the fact of visual imprinting, which played a key role in research in the 1930s, cannot explain the full range of behavioral acts that result in reproduction. Therefore, this article is devoted to highlighting imprinting issues that were not covered by K. Lorentz, requiring additional research, as well as to the facts that exist today, according to the observation data of modern ornithologists, zoo engineers, breeders and contrary to the outcomes of his research.

Keywords: imprinting, zoopsychology, ornithology, embossing, behavior.

Постановка проблеми. Останнім часом, у зв'язку зі збільшенням кількості центрів реабілітації птахів, намітилася тенденція вилучення 3 природи штучно вигодуваних людиною особин, а в середовищі заводчиків означилася тенденція продажу зграйних видів декоративних птахів у якості імпринтів, що не потребують парного утримання. Такі дії пов'язані з тим, що практики реабілітологи та заводчики, які пройшли опитування, базуються в своїх рішеннях на даних, отриманих К. Лоренцом в результаті досліджень імпринтингу на свійських птахах. Однак в спостереженнях сучасних фрахівців - орнітологів, та 30оінженерів, з'явилась неузгодженість 3 деякими положеннями, що були винесені К. Лоренцом зйого досліджень. Наведені ними дані, разом 3 зауваженнями окремих вчених, вказують на те, що потрібне дослідження додаткових аспектів імпринтингу, які не були висвітленні К. Лоренцом.

Аналіз останніх досліджень і публікацій. Згідно даних, наведених англійським нейрофізіо- логом Хорном Г. в його роботах присвячених дослідженню механізмів імпринтингу, в нервовій системі присутній вроджений механізм вивільнення, але в його активації беруть участь не лише зорові рецептори. У своїй монографії [2] він наводить результати експериментів по визначенню відділу мозку, що відповідає за відкарбовування. Тваринам вводили речовину, помічену радіоактивним ізотопом і на радіографії відстежували дію ціеї речовини в РНК. Крім цього, в організм тварин вводили 2-дезоксиглюкозу і по їі накопиченню в організмі визначали активність.

Виділення невирішених раніше частин загальної проблеми. 3 огляду на те, що дослідження К. Лоренца, проводилися головним чином на пташенятах, що народжуються повністю сорормованими та готовими до слідування, відносно яких і фрункціонувало правило перших 13 годин, протягом яких йшов процес відкарбовування образу матері, за межами досліджень опинилися види, пташенята, яких народжують- 
ся нездатними до самостійного життя та проводять від одного до трьох тижнів у гнізді, спираючись виключно на тактильні, звукові, та нюхові фрактори. Також, сучасними орнітологами та зооінженерами фріксуються фракти можливості розмноження імпринтованих птахів, всупереч досліджень К. Лоренца.

Мета статті. Головною метою ціеї роботи є виділення існуючої проблеми в дослідженнях імпринтингу та наведення прикладів сучасних спеціалістів, що доводять неузгодженість 3 дослідженнями 30-х років XX ст., а тому питання потребує подальшіх дослідів.

Виклад основного матеріалу. Працюючи 3 фрахівцями в галузі реабіліталогії птахів, все частіше доводиться стикатися 3 певними упередженнями людей щодо можливостей виживання та розмноження птахів, що були вигодовані штучно.

На жаль, більшість, спираючись на досвід К. Лоренца в питаннях імпринтингу, вважають випуск таких особин неможливим у зв'язку з нездатністю штучно вигодованих птахів до адаптації у дикій природі, залишаючи вирощеного в птаха в неволі, без партнера протилежної статті, породжуючи тим самим нові проблеми, як для себе, так і для нього.

Вважаємо, тут необхідно внести деякі корективи до розуміння інстинктів i імпринтингу, спираючись не тільки на класичні наукові дані, які стосуються початку минулого століття, але і з огляду на сучасні спостереження фрахівців, що працюють з птахами.

Корективи стосуватимуться низки висловлюваних, зазвичай, положень і в їх основі буде лежати наукове розуміння імпринтингу, пробіли в дослідженні імпринтингової поведінки, які на сьогоднішній день зустрічаються і являються приводом для продовження досліджень, а також інстинкти, генетичне і внегеномне спадкування, яке ми зможемо спостерігати, спираючись в тому числі, на роботи К.Е. Фабрі.

Імпринтинг/фіксування, відкарбовування.

Проблемою імпринтингу займалися Д. Сполдінг (Spalding, 1873), який зауважив, що як тільки курчата можуть ходити, вони починають слідувати за будь-яким об'єктом, що рухається, О. Хейнрот, що розширив спостереження.

Але основний інтерес до питання імпринтингу, з'явився після робіт Конрада Лоренца.

Згідно його досліджень, для новонароджених гусей, каченят, перший зустрічний в полі зору об'єкт виступав, як привабливий символ, за яким вони йшли, не усвідомлюючи роль і призначення самого об'єкта.

Вилупившись 3 яйця, пташенята були зайняті пошуком «образу матері». Для визначення своєї матері вони відокремлювали всього лише одну конкретну субмодальність. Сдине, що мала робити їх мати - це рухатися.

Статева програма згодом реалізовувалася так само 3 тим об'єктом, який був ідентифрікований малюком як мати, навіть якщо це був звичайний предмет - м'ячик, кулька, який К. Лоренц використовував в вході вивчення питання.

Періодом, коли реалізовувався імпринтинг, вибір об'єкта слідування, у птахів було прийнято вважати - першу добу, точніше 13 годин від народження.
Неузгодженість дослідів 3 сучасною практикою.

Згідно спостережень сучасних фрахівців, що пращюють з птахами, є фракти, що не вписуються в загальну модель К. Лоренца $30-x$ років:

- окремі види диких качок, починають видавати характерні звуки призову пташенят, ще в період висиджування кладки і пташенята вилуплюючись, реагують на матір не просто як на перший об'єкт що рухається, а як на джерело тих звуків, які вона видавала ще в період висиджування. Це руйнує певною мірою схему просто рухомого об'єкта як материнського зразка.

- вплив на процес відкарбовування/імпринтингу перших тактильних відчуттів, запахів i звуків, за якими пташенята, що народжуються нерозвиненими, сліпими, вже орієнтуються на материнський об'єкт, на що вказуеться у роботах Хорна Г. (1988). Даний фрактор названо вродженим механізмом вивільнення, для приведення в дію якого, потрібні рецепторні подразники не тільки зорові але й нюхові, тактильні або інші. Цей аспект не відображено в звітах К. Лоренца у зв'язку з тим, що експерименти проводилися на качках, гусятах, які народжуються вже сформованими. Але він є і вимагає вивчення.

- здатність до розмноження птахів що попали в реабілітаційні центри не зрячими, або були відняті від батьків до перших 13 годин з моменту появи зору.

Згідно висновків К. Лоренца і ряду інших дослідників, чистим імпринтом $е$ пташеня взяте з гнізда в першу добу свого життя, яке орієнтується саме на візуальний контакт. Але що ж відбувається 3 птахами інших видів, у яких пташенята народжуються несформованими та сліпими? Тут ми можемо звернутися до досвіду заводчиків декоративних птахів, пращівників реабілітаційних центрів, зооінженерів.

Практичний досвід сучасних фахівців.

3 огляду на те, що декоративні птахи в неволі народжуються повністю не пристосованими і залежними від батьків, на відміну від гусенят і каченят, деякі заводчики, спираючись на досліди К. Лоренца, орієнтуються на зоровий контакт, як на ключовий фрактор фріксації батьківського об'єкта і в залежності від виду птаха, намагаючись виховати імпринта, забирають пташеня з гнізда, у віці від одного до трьох тижнів, в залежності від того коли у нього відкриваються очі.

Тобто, як ми бачимо, основний акцент заводчиками робиться саме на зоровий контакт. Заводчик переслідуе мету, зробити так, щоби першим об'єктом, який опиниться в полі зору пташеня, була людина.

Але, при џьому перші один - три тижні, пташенята проводять у тактильних відчуття, звуках і запахах, властивих їх біологічним батькам, а не людині, та як показуе практика самих заводчиків, виростаючи таким чином, не виходять 3 програми розмноження.

Спостереження цього процесу проводилися спеціалістами-заводчиками м. Одеси - Арабською В.Л. та Супруном А.М. із залученням конкретних видів папуг: неразлучники, трав'яний попуга, аратинги, каліта-монах, сенегальські та ожереловий папуги. 
Птахів цих видів, вилучених спираючись виключно на зоровий контакт як причину слідування зі збереженою фрункцією розмноження - не можна віднести до чистого імпринту, а значить олюднити в його бажаннях і прагненнях теж не вдасться.

Розглядаючи питання імпринтинга 3 опорою на позищію К. Лоренца, слід звернути увагу і на сучасний досвід сокольників, фрахівців центрів, які займаються вирощуванням хижіх птахів-імпринтів, лікуванням, та вигодовуванням диких птахів.

В даному випадку, вилучення з гнізда так само здійснюється в ранньому періоді. Але, при цьому, зростаючи, птах, всупереч експериментів К. Лоренца, також зберігає здатність до розмноження. При проведенні ж належної підготовки легко дичає, стаючи придатним для випуску в природу.

I нарешті досвід сучасної зооінженерії. Згідно даних наданих Подніколенко Ю.Н. спеціалістом-птаховодом Петрівського господарства Лиманського району, Одеської області, на базі якого він проводив спостереження, свійськи качки та кури, вирощені в умовах інкубатору та вигодовані людьми - розмножуються. Деякі труднощі стосовно інкубаторської свійської птиці, за його словами, можуть зустрічатися тільки у відношені гусей, але не завжди.

На ту ж особливість саме гусей, правда, на цей раз диків видів, вказує провідний спеціаліст Одеського зоопарку, орнітолог Пілюга В.I., гусей на базі експерементів з якими, було вибудовано та в деякій мірі узагальнено поняття імпринтингу К. Лоренцом.

Одже в цілому, невідповідність досвіду сокольників, заводчиків декоративних птахів, зооінженерів, результатам запропонованими К. Лоренцом і питання періоду фріксації, відкарбовування у птахів, що народжують несформованих пташенят, ставить нові завдання перед дослідниками.

Питання наявності інстинктів штучно вигодуваних птахів.

Тепер звернемося до проблеми інстинктів, які впираються в питання - чи можливі полювання, розмноження, дичання птахів, вирощених людиною.

На сьогоднішній день, виділяють дві фрорми передачі спадкової інформації - генетична і внегеномно успадкована/соціальна.

Генетична - заснована на передачі інформаціï, яка зберігається у вигляді схильностей до певних форм поведінки. Сучасна генетика не володіє даними про специфіку протікання процесу прописування даних програм в генетичному коді, проте підтверджує даний фракт.

Це загальнобіологічий закон, для всіх видів включаючи людину. У людини це особливо добре видно на прикладі усиновлених дітей, коли у дитини в певному віці можуть починатися прояви якостей не властивих прийомним батькам, які, в свою чергу задаються питанням «звідки не характерна поведінка з'явилась, якщо дитина в новій сім'ї виховувалась 3 народження?».
Це еволюційний механізм. Кожне нове покоління повинно бути досконаліше попереднього, тому весь комплекс дій/досягнень вироблених дорослими особами в попередніх поколіннях, який призвів до їх фрізичного виживання, визнаеться успішним і передаеться з генетичним кодом в процесі зачаття наступним поколінням.

3 цієї причини, наприклад, діти що виросли в сім'ї розведених батьків, виростаючи, розлучаються майже в ста відсотках випадків. Знову-таки, навіть якщо діти не знали, що хтось із батьків мав раніше іншу сім'ю. Вони просто, не підозрюючи, реалізують передану батьками генетичну і внегеномну зв'язку.

I тут ми вже звертаємося до згаданого К.Е. Фабрі. Це не просто генетика це тісний зв'язок генетично переданих схильностей і внегеномноуспадкованих соціальних інстинктів, які $\epsilon$ по суті навчанням, списанням програм поведінки 3 дорослої особи. Природа відбивання психіки, взаємозв'язку психіки і поведінки, тісне співвідношення не тільки набутого але і вродженого.

Таким чином, повертаючись до нашого питання, пара птахів, як і пара людей, що виросла в умовах повної ізоляції нічого не знаючи про розмноження все одно з максимальною часткою ймовірності розмножиться, такий закон вроджених інстинктів.

В цьому їх призначення, щоб за будь-яких обставин, минаючи соціальні стандарти, відсутність інформащії, правила пристойності, комплекси - домінування, виживання, розмноження як базові програми були реалізовані і життя не припинилося.

Висновки і пропозиції. Незважаючи на те, маємо ми справу з, так званим, «чистим» імпринтом, вилученим 3 гнізда в першу добу життя або це птах, якого забрали від батьків через один-три тижні, інстинкти ніхто не відміняе і програма «домінування-виживання-розмноження» керує живою істотою в повній мірі.

Тому вольерне життя в умовах вилучення від собі подібних, коли організм тварини знищуеться власними гормонами, без реалізації себе в умовах зграї, тому, що у людей прийнято тримати в ізоляції, як не дивно, саме стайних птахів - папуги, амадини, підібрані пташенята шпаків, горобців, вранових, ін., а життя таких птахів, всі ïx інстинкти націлені на виживання саме в умовах зграї - однозначне насильство над твариною та ломка природних програм.

Спираючись на спостереження окремих практиків та вчених, наведені в даній статті, можна вважати за потрібне, проводити нові дослідження із залученням досвіду сучасних заводчиків, пращівників реабілітаційних центрів, зооінженерів. Такі дослідження, дозволили б у рамках зоопсихології, сформувати максимально адаптовну до реального життя модель фріксування програм дорослих особин птахами різних видів, та внести корективи в роботу багатьох заводчиків та реабілітологів, що спираються у своїй діяльності на результати досліджень сучасної науки.

\section{Список літератури:}

1. Зеляк А.В. Імпринтинг як застава психічного і фрізичного здоров'я : IV міжнар. наук.-практ. конф. (Новосибірськ, 4-9 листопада 2009 р.). Новосибірськ, 2009. С. 13-14.

2. Зоріна З.А., Полетаєва I.І. Зоопсихологія. Елементарне мислення тварин. Москва : Аспект-пресс, 2010.320 с. 
3. Мандель Б.Р. Зоопсихологія та порівняльна психологія. Мосвка : Гео, 2014. 301 с.

4. Москалец В.П. Зоопсихологія і порівняльна психологія : Підручник. Київ : Центр учбової літератури, 2014.198 с.

5. Мак-Фарленд Д. Поведінка тварин: Психобіологія, етологія і еволюція. Москва : Мир, 1988. 5201 с.

6. Семенченко С.В., Засемчук И.В. Вирощування качки крякви для мисливських господарств. Д.: ДДАУ, 2016. 64 с.

7. Фабрі К.Е. Основи зоопсихології. Москва : МДУ, 1976. 288 с.

8. Фабрі К.Е. Основи зоопсихології. Москва : МДУ, 1993. 336 с.

9. Хорн Г. Пам'ять, імпринтинг та мозок. Москва : Мир, 1988. 344 с.

10. Лоренц К. Рік сірого гуся. Москва : Мир, 1984. 191 с.

\section{References:}

1. Zeljak A.V. (2009). Impryntyngh jak zastava psykhichnogho i fizychnogho zdorov'ja: IV mizhnar. nauk.-prakt. konf. (Novosybirsjk, 4-9 lystopada 2009 r.). Novosybirsjk, pp. 13-14.

2. Zorina Z.A., Poljetajeva I.I. (2010). Zoopsykhologhija. Elementarne myslennja tvaryn. Moscow: Aspekt-press, 320 p.

3. Mandelj B.R. (2014). Zoopsykhologhija ta porivnjaljna psykhologhija. Moscow: Gheo, $301 \mathrm{p}$.

4. Moskalecj V.P. (2014). Zoopsykhologhija i porivnjaljna psykhologhija: Pidruchnyk. Kyiv: Centr uchbovoji literatury, 198 p.

5. Mak-Farlend D. (1988). Povedinka tvaryn: Psykhobiologhyja, etologhija i evoljucija. Moscow: Myr, 5201 p.

6. Semenchenko S.V., Zasemchuk Y.V. (2016). Vyroshhuvannja kachky krjakvy dlja myslyvsjkykh ghospodarstv. D.: DDAU, $64 \mathrm{p}$.

7. Fabri K.E. (1976). Osnovy zoopsykhologhiji. Moscow: MDU, 288 p.

8. Fabri K.E. (1993). Osnovy zoopsykhologhiji. Moscow: MDU, 336 p.

9. Khorn Gh. (1988). Pam'jatj, impryntyngh ta mozok. Moscow: Myr, 344 p.

10. Lorenc K. (1984). Rik sirogho ghusja. Moscow: Myr, 191 p. 